\title{
The role of endophyte in determining the persistence and productivity of ryegrass, tall fescue and meadow fescue in Northland
}

\author{
D.E. HUME ${ }^{1}$, B.M. COOPER ${ }^{2}$ and K.A. PANCKHURST ${ }^{2}$ \\ ${ }^{1}$ AgResearch, Grasslands Research Centre, Private Bag 11008, Palmerston North 4442, New Zealand \\ ${ }^{2}$ AgResearch, Kerikeri Research Centre, PO Box 23, Kerikeri 0245, New Zealand
}

${ }^{1}$ david.hume@agresearch.co.nz

\begin{abstract}
Evidence from small plot and farm trials demonstrate that fungal endophyte infection plays a pivotal role in enhancing the persistence and yields of perennial, hybrid and Italian ryegrasses, tall and meadow fescues in Northland. In most situations these effects were evident within 2-3 years of sowing and were largely attributed to protection from insect attack that is conferred by endophyte infection. Many trials suffered from attack by African black beetle but root aphids were also important in one trial. For ryegrasses, there were differences between the effectiveness of the endophytes, with the AR37 strain imparting the best agronomic performance to the infected ryegrass cultivar.
\end{abstract}

Keywords: fungal endophyte, Neotyphodium, perennial ryegrass, Lolium perenne, tall fescue, Festuca arundinacea, meadow fescue, Festuca pratensis, African black beetle, Heteronychus arator

\section{Introduction}

Yields and persistence of temperate grasses in Northland are limited by unreliable summer rains, competitive subtropical grasses and damage from insect pests, particularly African black beetle (Heteronychus arator). There is considerable evidence to show that infection with fungal endophyte (Neotyphodium spp.) is a crucial factor in determining the performance of ryegrasses (Lolium spp.) in New Zealand (NZ), primarily through protection from insect pests (Popay et al. 1999; Popay \& Thom 2009, this volume). Tall fescue (Festuca arundinacea) and meadow fescue (F. pratensis) may also have enhanced survival when infected with endophyte for similar reasons (Fletcher et al. 2001; Popay et al. 2005). This paper examines the role endophytes have in enhancing the agronomic performance of temperate grasses in Northland. Data from several small plot and farm trials are presented and previously published information is reviewed.

\section{Materials and Methods}

Small plot trials were carried out using the protocols described by Hume et al. (2007). In brief, trial plots were hand-sown into cultivated seedbeds in autumn with fertiliser applied to correct any soil nutrient deficiencies. Ryegrasses, tall fescue and meadow fescue seeds were sown at $20-25 \mathrm{~kg} / \mathrm{ha}$ and herbicides were used to eliminate or reduce the presence/growth of other species in the plots. Nitrogen fertiliser was applied, usually as urea $(46 \% \mathrm{~N})$, after each grazing at rates of 30-100 kg N/ha, depending on soil type. Trials were usually replicated in four randomised blocks and plots were $5-11 \mathrm{~m}^{2}$ in size.

Most ryegrass trials compared agronomic performance of an endophyte-free cultivar with the same cultivar infected with its resident common endophyte referred to as Standard (= wild-type), and selected endophyte strains (Table 1). Trials with tall fescue evaluated several cultivars without endophyte or infected with different non-toxic endophyte strains (Table 2). Meadow fescue infected with its natural endophyte, $N$. uncinatum, was included in some of the tall fescue trials.

Trials were usually assessed for dry matter (DM) yields by mowing a strip from each plot, weighing the cut herbage, and then oven-drying a subsample of the cut herbage to determine DM content. On some occasions a calibrated rising plate meter was used to assess yields. After each yield assessment, plots were grazed by sheep for 24 to $48 \mathrm{~h}$, with any uneven residuals mown to the lowest grazing height. On-farm trials used grazing exclusion cages from which the herbage was occasionally cut to determine DM yields (6-7 cuts per annum) over 2-3 years. When the sown grass content declined below $95 \%$ of the cut herbage, botanical composition was determined usually through the dissection of subsamples of herbage. Immunoblot tests for endophyte presence in tillers was conducted on all plots at the beginning of the trials to confirm endophyte status i.e. highly infected with endophyte $(>70 \%)$ and endophyte-free/very low infection rate $(<10 \%)$.

On occasions when damage from African black beetle was apparent, plots were scored for the number of plants showing signs of larval damage (see Hume et al. 2007). In one trial, root aphid (Aploneura lentisci) infestation was scored as the number of colonies in four spade squares per plot (Hume et al. 2007).

All statistical analyses were performed as ANOVA using GenStat $11^{\text {th }}$ Edition. 
Table 1 DM yields of endophyte-infected ryegrass relative to endophyte-free (Nil), or AR1-infected ryegrass, within the same cultivar for small plot trials at Kerikeri. Means followed by the same letter within a row do not differ significantly at $P>0.05$.

\begin{tabular}{|c|c|c|c|c|c|c|c|}
\hline \multirow[b]{2}{*}{ Year sown } & \multirow[b]{2}{*}{ Cultivars $^{\mathrm{A}}$} & \multirow[b]{2}{*}{ Year } & \multicolumn{4}{|c|}{ Yield relative to Nil or AR1 $(=100)$} & \multirow{2}{*}{$\begin{array}{c}\text { Significance } \\
\text { level }^{\mathrm{B}}\end{array}$} \\
\hline & & & Nil & AR1 & Standard & AR37 & \\
\hline \multirow[t]{3}{*}{1996} & 'G. Nui’ & 1 & 100 & 106 & 106 & 107 & NS \\
\hline & & 2 & $100 \mathrm{a}$ & $104 a$ & $123 \mathrm{~b}$ & $146 \mathrm{c}$ & * \\
\hline & & 3 & $100 \mathrm{a}$ & $130 a b$ & $142 \mathrm{~b}$ & $189 \mathrm{c}$ & * \\
\hline \multirow[t]{3}{*}{1997} & ‘G. Nui’ & 1 & 100 & 110 & 96 & 113 & NS \\
\hline & & 2 & $100 \mathrm{a}$ & $116 a b$ & $106 a$ & $131 \mathrm{~b}$ & * \\
\hline & & 3 & $100 \mathrm{a}$ & $111 \mathrm{ab}$ & $133 \mathrm{~b}$ & $194 \mathrm{c}$ & * \\
\hline \multirow[t]{2}{*}{2000} & 6 cultivars $^{c}$ & 1 & $100 \mathrm{a}$ & $102 \mathrm{a}$ & $109 \mathrm{~b}$ & & * \\
\hline & & 2 & $100 \mathrm{a}$ & $103 a$ & $112 \mathrm{~b}$ & & * \\
\hline \multirow[t]{2}{*}{$2001(a)$} & 'G. Kamo’ & $1-3$ & & 100 & 101 & & NS \\
\hline & 'G. Samson' & $1-3$ & & 100 & 104 & 105 & NS \\
\hline \multirow[t]{3}{*}{ 2001(b) } & 'G. Samson' D & 1 & & $100 \mathrm{a}$ & $112 \mathrm{a}$ & $131 b$ & * \\
\hline & & 2 & & $100 \mathrm{a}$ & $110 \mathrm{a}$ & $157 \mathrm{~b}$ & * \\
\hline & & 3 & & $100 \mathrm{a}$ & $93 a$ & $172 b$ & * \\
\hline \multirow[t]{3}{*}{2005} & 'G. Samson’ & 1 & $100 \mathrm{a}$ & $133 b$ & $144 \mathrm{~b}$ & $173 c$ & * \\
\hline & & 2 & $100 \mathrm{a}$ & $119 b$ & $135 c$ & $139 \mathrm{c}$ & * \\
\hline & & 3 & $100 \mathrm{a}$ & $135 b$ & $136 \mathrm{~b}$ & $161 \mathrm{c}$ & * \\
\hline
\end{tabular}

A All cultivars are perennial ryegrass (L. perenne) except for 2000-sown trial. 'G.' = 'Grasslands'

${ }^{\text {B }} \mathrm{NS}=$ not significant $(\mathrm{P}>0.05),{ }^{*}=$ significant $(\mathrm{P}<0.05)$

C Mean of perennial cultivars 'Grasslands Nui', 'Grasslands Pacific', 'Grasslands Samson', and long-rotation hybrid cultivars 'Grasslands Impact', 'Grasslands Supreme', 'Grasslands Marsden'

D Adapted from Hume et al. (2007)

\section{Results and Discussion}

\section{Perennial and long-rotation hybrid ryegrasses}

In 1988 ryegrass plants were collected from old ryegrass pastures ( $>20$ years of age) in Northland, from Te Paki in the north to Warkworth in the south. Cooper \& Farrelly (1989) tested these plants for endophyte presence in summer 1988/89. Of the 290 plants collected from 29 sheep/beef farms, $99 \%$ were infected with endophyte (N. lolii), while the 310 plants collected from 31 dairy farms were infected at the rate of $94.8 \%$. A further $1.3 \%$ of plants from dairy farms were infected the $N$. occultans endophyte, indicating that the collection contained Italian (L. multiflorum) and/or short-rotation hybrid (L. boucheanum) ryegrasses. Such high infection rates from old pastures are a strong indicator of the importance of endophyte infection in determining grass persistence (Hume \& Barker 2005).

Small plot trials determining the role of endophyte absence/presence and endophyte strain in agronomic performance of ryegrass began in the mid-1990s at Kerikeri (Table 1). Endophyte infection significantly improved yields in all four trials where endophytefree was compared with endophyte-infected. For these particular trials, this effect was significant in Year 1 in two trials and significant in all trials in Years 2 and 3. In general, differences became greater over time. Differences occurred between endophyte strains. While AR1 ryegrass was always numerically higher yielding than endophyte-free, this difference was only statistically significant $(\mathrm{P}<0.05)$ in 3 out of the 11 years where these comparisons were made. In contrast, Standard ryegrass out-yielded endophyte-free $(\mathrm{P}<0.05)$ in 8 of these 11 years and AR37 ryegrass out-yielded endophytefree in 7 of 9 years. For the endophyte-infected lines, on average AR1 ryegrass was the lowest yielding, Standard was intermediate and AR37 was highest. Yields were significantly greater for Standard ryegrass than AR1 ryegrass in 4 of 16 annual comparisons and for AR37 ryegrass over AR1 in 9 of 13 comparisons. In the 2000-sown trial, all cultivars responded in a similar manner to the endophyte treatments, except for 'Grasslands Pacific' and 'Grasslands Samson' in Year 1 
Table 2 DM yields of endophyte-infected relative to endophyte-free tall fescue within the same cultivar for four small plot trials at Kerikeri. All infected cultivars contained the endophyte strain AR542 (now marketed as MaxP ${ }^{\circledR}$ ), except for 'Grasslands Advance' in the 1997-sown trial (mean of AR501 and AR502) and 'Taita' (mean of AR524 and AR584).

\begin{tabular}{|c|c|c|c|c|}
\hline Year sown & Cultivars $^{\mathrm{A}}$ & Year & $\begin{array}{l}\text { Yield advantage to } \\
\text { endophyte-infected line }\end{array}$ & $\begin{array}{l}\text { Significance } \\
\text { level }^{\mathrm{B}}\end{array}$ \\
\hline \multirow[t]{3}{*}{1997} & \multirow[t]{3}{*}{ 'G. Advance' } & 1 & $+30 \%$ & * \\
\hline & & 2 & $+59 \%$ & * \\
\hline & & 3 & $+51 \%$ & * \\
\hline \multirow[t]{3}{*}{2000} & \multirow{3}{*}{$\begin{array}{l}\text { Mean of 'G. Advance', } \\
\text { 'Quantum' \& 'Resolute' }\end{array}$} & 1 & $+2 \%$ & NS \\
\hline & & 2 & $+14 \%$ & * \\
\hline & & 3 & $+19 \%$ & * \\
\hline \multirow[t]{3}{*}{2005} & \multirow{3}{*}{$\begin{array}{l}\text { Mean of 'Jesup' \& } \\
\text { 'Quantum' }\end{array}$} & 1 & $+13 \%$ & * \\
\hline & & 2 & $+16 \%$ & * \\
\hline & & 3 & $+18 \%$ & NS \\
\hline \multirow[t]{2}{*}{2006} & \multirow{2}{*}{$\begin{array}{l}\text { Mean of 'G. Advance', } \\
\text { 'Taita' \& 'G. Flecha' }\end{array}$} & 1 & $-4 \%$ & NS \\
\hline & & 2 & $+65 \%$ & * \\
\hline
\end{tabular}

A 'G.' = 'Grasslands'

B NS = not significant $(P>0.05),{ }^{*}=$ significant at $\mathrm{P}<0.05$

when endophyte-free was lower yielding than AR1 (data not shown).

The 2005-sown trial also included other cultivars infected with AR37 (x2), AR1 (x8) and AR6 (x1). Plots suffered severe damage from African black beetle in the summer of Years 2 and 3. DM yields during these periods were highly correlated with scores of African black beetle larval damage $(\mathrm{P}<0.001$ in both years $)\left(\mathrm{r}^{2}=\right.$ $52 \%$ and $63 \%$, respectively), similar to that reported by Popay et al. (1999). Cultivars infected with AR37 and the two endophytes producing ergovaline (Standard, AR6) had the lowest damage scores, and endophytefree the highest. Damage in the nine AR1-infected cultivars ranged from high (similar to endophyte-free) to low (similar to AR37, Standard, AR6), indicating a strong interaction of AR1 with different cultivars.

In contrast to other trials, the 2001-sown trial ('Grasslands Samson'-only trial) had no African black beetle when sampled in Year 2 and no African black beetle damage to ryegrass was apparent in Year 3. What did differ between treatments were infestations of root aphid. Population scores for root aphid were highest in AR1 ryegrass, lowest in AR37, and intermediate in Standard, and were inversely correlated to yields (Hume et al. 2007). This is consistent with field trials in Canterbury (Pennell et al. 2005) and pot trials (Popay \& Gerard 2007).

Results of the small plot trials have been confirmed in two unreplicated on-farm trials (sown strips in paddocks). On a dairy farm near Kerikeri airport, total pasture and ryegrass yields were higher in 'Grasslands Samson' AR37 ( $+6 \%$ and $+14 \%$, respectively) than 'Grasslands Samson' Standard. The largest differences occurred in summer/autumn, particularly in Year 3 during drought and high populations of African black beetle, when AR37 yielded up to $180 \%$ more ryegrass and $144 \%$ more total pasture than Standard. AR37 also had notably less invasion from kikuyu (Pennisetum clandestinum) (5\% of total green yield) than Standard (59\%). Further north at Houhora, 'Grasslands Samson' AR37 yielded 23\% more ryegrass than 'Grasslands Samson' Standard over 2 years, with AR37 pastures tending to have higher contents of ryegrass than Standard (54\% and 49\%, respectively) and less kikuyu ( $20 \%$ and $23 \%$, respectively). By comparison, in a replicated milk production trial near Dargaville, AR1 yielded $2 \%$ and $9.3 \%$ less total pasture than Standard in Years 1 and 2, respectively (Ussher 2003).

\section{Annual/Italian ryegrasses}

Cultivars of these ryegrasses, particularly those based on NZ ecotypes, can be infected with fungal endophyte (N. occultans) (Forde et al. 1988; Latch et al. 1988). Piggot et al. (1988) found 15\% of hybrid ryegrasses collected from old pastures in Northland were infected with $N$. occultans. This endophyte is confined to the basal parts of the plant and seedheads, and offers far less protection to the plant than the endophyte $(N$. 
lolii) infecting perennial and long-rotation hybrid ryegrasses. Studies in other areas of NZ indicate that infection with $N$. occultans increases annual/Italian ryegrass growth and survival primarily at the time of seedling establishment (Hume et al. 1993), which is likely to be driven at least partly by the protection this endophyte imparts to seedlings from Argentine stem weevil (Listronotus bonariensis) attack (Stewart 1987). In trials at Kerikeri, Cooper et al. (2007) reported plant survival and production advantages to $N$. occultansinfected 'Corvette' Italian ryegrass compared with low or endophyte-free lines of 'Corvette'. These advantages ( $+35 \%$ for DM yield over 2.5 years) did not occur at the establishment phase, but occurred from mid-autumn of Year 1 onwards after damage from African black beetle in the preceding summer. Currently there are no cultivars marketed in NZ with a guaranteed minimal level of $N$. occultans, but the results from Northland and other areas in NZ provide support for such cultivars to be developed for the NZ market.

$N$. lolii, the endophyte from perennial ryegrass, naturally occurs in hybrid ryegrasses in Northland (Piggot et al. 1988) and the Waikato (Hume et al. 2001) but only in those plants with morphological characteristics consistent with long-rotation hybrids. Short-rotation/Italian and annual ryegrasses have been inoculated with $N$. lolii strains and trialled in Northland (Cooper et al. 2007). Lines of 'Grasslands Moata' tetraploid Italian ryegrass infected with AR5 endophyte were trialled at Kaikohe in an area where African black beetle is absent as soil conditions are unfavourable for survival of this insect. Most lines yielded below the endophyte-free control and none were higher yielding than the control. In contrast, at Kerikeri, 'Corvette' and 'Status' Italian ryegrasses infected with AR1 were more productive than endophyte-free or when infected with $N$. occultans, and further advantages were gained with AR37. As with other ryegrass trials at this location, yield differences developed after attack from African black beetle over the preceding summer (Cooper et al. 2006).

\section{Tall fescue}

Naturalised tall fescue occurs along roadsides and waterways, and in some districts, in pastures and grazed wastelands. It is usually infected with an endophyte that has been associated with heat stress in cattle in Manawatu and Northland (Easton et al. 1994; Guy \& Davis 2002; Kearns 1986). The first indication that endophyte infection could impart an agronomic advantage to tall fescue was from a small plot trial sown at Kaikohe in 1991 (Easton \& Cooper 1997) where the rate of infection from a contaminating endophyte in cv. 'Grasslands Advance', increased from 30\% at sowing to $80 \%$ of tillers 4 years later. Over time, 'Grasslands
Advance' out-yielded ryegrasses in the trial in the late summer and autumn, and out-yielded an endophytefree tall fescue, 'Grasslands Roa'.

'Grasslands Advance' tall fescue was subsequently evaluated in small plots at Kerikeri in 1997 with various endophyte strains that were not toxic to livestock (Cooper et al. 2002). Within the first year, 'Grasslands Advance' infected with two of these strains (AR501 and AR502) (Ball \& Tapper 1999) had better agronomic performance than 'Grasslands Advance' free of endophyte (Table 2). Yield advantages to endophyteinfected lines were greater in subsequent years, and 5 years after sowing plant numbers were $66 \%$ higher in endophyte-infected than endophyte-free plots $(\mathrm{P}<0.05)$. Differences in yields were greatest in late summer and early autumn, coinciding with higher damage from adult African black beetle in the latter plots $(23 \%$ and $5 \%$ tiller damage, respectively) (Popay et al. 2005).

Further trials at Kerikeri have shown that selected nontoxic endophytes can impart agronomic advantages to a wide range of cultivars (Table 2). Trials sown in 2000, 2005 and 2006 included cultivars 'Grasslands Advance', 'Quantum', 'Jesup' and 'Taita', as well as 'Grasslands Flecha' and 'Resolute' which have a Mediterranean-type growth pattern. For all cultivars endophyte infection increased productivity over endophyte-free within the same cultivar (Table 2), particularly in late summerautumn (data not shown). On occasions cultivars responded differently (significant endophyte $\mathrm{x}$ cultivar interactions) but there were no consistent patterns.

In 2001, paddocks on three farms in Northland were split and sown to either 'Quantum' AR542 or 'Quantum' endophyte-free, both with red and white clovers, replicated twice. The only pastures to fully establish were those west of Kerikeri at Ohaeawai, and near Dargaville, both grazed by cattle. Three years after sowing there were more $(\mathrm{P}<0.05)$ tall fescue tillers in endophyte-infected than endophyte-free pastures (20 and 12 tillers per $30 \mathrm{~cm}$ length, respectively) at Ohaeawai, while similar visual differences were apparent at Dargaville. As occurred in the small plots, tiller damage caused by adult African black beetle was higher in endophyte-free $(23 \%)$ than endophyteinfected pastures (1\%) at Ohaeawai (Popay et al. 2005). Larval damage to tillers caused by Argentine stem weevil, as measured at both farm sites, was low but less on endophyte-infected (1\%) than endophyte-free (7\%) tall fescue, consistent with laboratory studies (Popay et al. 2005).

\section{Meadow fescue}

There is indirect evidence that endophyte (N. uncinatum) infection will enhance the agronomic performance of meadow fescue in Northland. Endophyte was found to 
be infecting all meadow fescue plants collected from a farm near Kaitaia where this grass was reported as "common and widespread" and "provided valuable summer and autumn feed during drought years" (Cooper 1996). When evaluated at Kaikohe these plants out-performed endophyte-free overseas meadow fescue cultivars, with some of the Kaitaia plants yielding better than endophyte-free 'Grasslands Advance' tall fescue but only in Year 1. The best meadow fescue lines were bulked and evaluated alongside tall fescue in the 2005sown Kerikeri trial. Yields of meadow fescue over the trial period $(8700 \mathrm{~kg} \mathrm{DM} / \mathrm{ha} / \mathrm{yr})$ were similar to endophyte-free 'Jesup' (10400 kg DM/ha/yr) (P>0.05), but less than endophyte-free 'Quantum' (12000 kg DM/ $\mathrm{ha} / \mathrm{yr})(\mathrm{P}<0.05)$, while the endophyte-infected lines of 'Quantum' and 'Jesup' yielded an additional 16\% over their endophyte-free counterparts.

No comparisons of the Kaitaia meadow fescue seed line with and without endophyte have been made in Northland but they were evaluated in an unreplicated trial at Lincoln (Fletcher et al. 2001). Here, the endophyte-infected sward in Year 2 was higher yielding than the endophyte-free, and this corresponded to lower numbers and weights of grass grub larvae in endophyteinfected meadow fescue. The effect of endophyte in meadow fescue on grass grub was further confirmed in laboratory studies (Popay et al. 2003).

While these results show that endophyte-infection of meadow fescue may greatly enhance the agronomic performance of this grass in Northland, and other locations in NZ, current information indicates the Kaitaia line is not productive enough to be comparable with endophyte-infected tall fescue and perennial ryegrass cultivars. However, given the non-toxic nature of endophyte-infected meadow fescue to livestock (Fletcher et al. 2001) and the effect on grass grub, consideration should be given to further developing improved meadow fescue germplasm infected with endophyte.

\section{Conclusions}

Endophyte undoubtedly has a pivotal role in enhancing the agronomic performance of ryegrasses, tall fescue and meadow fescue in Northland. There is clear evidence from the field that most endophytes impart resistance to ryegrass and tall fescue to protect them from African black beetle attack. Endophyte-enhanced agronomic performance may also be attributed to protection from root aphids, and possibly other insects that are detrimentally affected by the presence of endophyte e.g. pasture mealybug (Balanococcus poae). At the time of seed purchase, farmers in Northland should carefully consider the important role endophyte has in determining grass persistence and productivity, and when faced with a choice of endophyte strains, consider the range of pest protection each will offer (Popay et al. 1999; Popay \& Thom 2009, this volume) and any effects on animal health and productivity (Fletcher \& Sutherland 2009, this volume).

\section{ACKNOWLEDGEMENTS}

Anouck de Bonth, Michael Hickey and Wayne Simpson for endophyte testing. Vicky Rawnsley and Kevin Baxter for providing farm trial sites, and the many Northland farmers that allow AgResearch (DSIR) to collect plant material.

\section{REFERENCES}

Ball, O.J.-P.; Tapper, B.A. 1999. The production of loline alkaloids in artificial and natural grass/ endophyte associations. Proceedings of the 52nd New Zealand Plant Protection Society: 264-269.

Cooper, B.; Farrelly, J. 1989. Endophyte levels in perennial ryegrass plants collected from Northland farms. Report DSIR Grasslands Division.

Cooper, B.; Hume, D.; Panckhurst, K.; Popay, A.; Lyons, T. 2006. The role of perennial ryegrass endophyte in Italian ryegrass. pp. 526-530. In: Breeding for success: diversity in action. Proceedings of the 13th Australasian Plant Breeding Conference. Ed. Mercer, C.F. New Zealand Grassland Association, Dunedin, New Zealand.

Cooper, B.M. 1996. Evaluation of a meadow fescue (Festuca pratensis) population from Northland. Proceedings of the New Zealand Grassland Association 57: 69-72.

Cooper, B.M.; Easton, H.S.; Hume, D.E.; Popay, A.J.; Baird, D.B. 2002. Improved performance in Northland of tall fescue with a novel endophyte. pp. 379-381. In: Proceedings of the 12th Australasian Plant Breeding Conference. Australasian Plant Breeding Association, Perth.

Cooper, B.M.; Hume, D.E.; Panckhurst, K.A.; Popay, A.J. 2007. Agronomic responses of Italian ryegrasses infected with different Neotyphodium strains. In: Proceedings of the 6th International Symposium on Fungal Endophytes of Grasses. Grassland Research and Practice Series 13: 297-300.

Easton, H.S.; Cooper, B.M. 1997. Field performance of tall fescue with low infection with Neotyphodium endophyte. pp. 251-253. In: Neotyphodium/grass interactions. Eds. Bacon, C.W.; Hill, N.S. Plenum Press, New York.

Easton, H.S.; Lee, C.K.; Fitzgerald, R.D. 1994. Tall fescue in Australia and New Zealand. New Zealand Journal of Agricultural Research 37: 405-417.

Fletcher, L.R.; Popay, A.J.; Stewart, A.V.; Tapper, B.A. 2001. Herbage and sheep production from meadow 
fescue with and without the endophyte Neotyphodium uncinatum. pp. 447-453. In: The grassland conference 2000. Fourth International Neotyphodium/ Grass Interactions Symposium. Eds. Paul, V.H.; Dapprich, P.D. Universitat Paderborn, Soest, Germany.

Fletcher, L.R.; Sutherland, B.L. 2009. Sheep responses to grazing ryegrass with AR37. Proceedings of the New Zealand Grassland Association 71: 127-132.

Forde, M.B.; Burgess, R.E.; Halligan, E.A.; Gardiner, S.E.; Latch, G.C.M. 1988. Varieties of Italian ryegrass in New Zealand. Proceedings of the New Zealand Grassland Association 49: 101-106.

Guy, P.L.; Davis, L.T. 2002. Disease notes or new records: Variation in the incidence of Barley yellow dwarf virus and in the ability of Neotyphodium endophytes to deter feeding by aphids (Rhopalosiphum padi) on Australasian tall fescue. Australasian Plant Pathology 31: 307-308.

Hume, D.E.; Barker, D.J. 2005. Growth and management of endophytic grasses in pastoral agriculture. pp. 201226. In: Neotyphodium in cool-season grasses. Eds. Roberts, C.A.; West, C.P.; Spiers, D.E. Blackwell Publishing, Ames, IA.

Hume, D.E.; Bluett, S.J.; Burggraaf, V.T.; Christensen, M.J. 2001. Occurrence of Neotyphodium endophytes in Italian/hybrid ryegrasses in dairy pastures. pp. 423-427. In: The grassland conference 2000. Fourth International Neotyphodium/Grass Interactions Symposium. Eds. Paul, V.H.; Dapprich, P.D. Universitat Paderborn, Soest, Germany.

Hume, D.E.; Christensen, M.J.; Hickey, M.J. 1993. Changes over time in the incidence of Acremonium endophyte in annual and short-lived hybrid ryegrass swards. pp. 210-213. In: Proceedings of the Second International Symposium on Acremonium/Grass Interactions. Eds. Hume, D.E.; Latch, G.C.M.; Easton, H.S. AgResearch, Palmerston North.

Hume, D.E.; Ryan, D.L.; Cooper, B.M.; Popay, A.J. 2007. Agronomic performance of AR37-infected ryegrass in northern New Zealand. Proceedings of the New Zealand Grassland Association 69: 201-205.

Kearns, M.P. 1986. Tall fescue toxicity: an investigation of idiopathic bovine hyperthermia (IBH) in the North Auckland peninsula. Proceedings of the New Zealand Grassland Association 47: 183-186.
Latch, G.C.M.; Christensen, M.J.; Hickson, R.E. 1988. Endophytes of annual and hybrid ryegrasses. New Zealand Journal of Agricultural Research 31: 57-63.

Pennell, C.G.L.; Popay, A.J.; Ball, O.J.-P.; Hume, D.E.; Baird, D.B. 2005. Occurrence and impact of pasture mealybug (Balanococcus poae) and root aphid (Aploneura lentisci) on ryegrass (Lolium spp.) with and without infection by Neotyphodium fungal endophytes. New Zealand Journal of Agricultural Research 48: 329-337.

Piggot, G.J.; Morgan, H.M.; Bakker, R.J. 1988. Endophytes in Northland ecotypes of hybrid ryegrass. Proceedings of the 41st Weed and Pest Control Conference 41: 129-131.

Popay, A.J.; Gerard, P.J. 2007. Cultivar and endophyte effects on a root aphid, Aploneura lentisci, in perennial ryegrass. New Zealand Plant Protection 60: 223-227.

Popay, A.J.; Hume, D.E.; Baltus, J.G.; Latch, G.C.M.; Tapper, B.A.; Lyons, T.B.; Cooper, B.M.; Pennell, C.; Eerens, J.P.J.; Marshall, S.L. 1999. Field performance of perennial ryegrass (Lolium perenne) infected with toxin-free fungal endophytes (Neotyphodium spp.). Ryegrass endophyte: an essential New Zealand symbiosis. Grassland Research and Practice Series 7: 113-122.

Popay, A.J.; Jensen, J.G.; Cooper, B.M. 2005. The effect of non-toxic endophytes in tall fescue on two major insect pests. Proceedings of the New Zealand Grassland Association 67: 169-173.

Popay, A.J.; Jensen, J.G.; Fletcher, L.R. 2003. The effect of endophyte (Neotyphodium uncinatum) in meadow fescue on grass grub larvae. New Zealand Plant Protection 56: 123-128.

Popay, A.J.; Thom, E.R. 2009. Endophyte effects on major insect pests in Waikato dairy pasture. Proceedings of the New Zealand Grassland Association 71: 121-126.

Stewart, A.V. 1987. Plant-breeding aspects of ryegrass (Lolium spp.) infected with endophytic fungus. Ph.D thesis. Lincoln College, Canterbury.

Ussher, G. 2003. Northlands pasture toxin project. pp. 62-64. In: New Zealand Large Herds Association Conference Proceedings. New Zealand Large Herds Association Inc. 